Original Research Paper

\title{
Personal Legacy Information Management System for Muslim in Malaysia: A Preliminary Design
}

\author{
Hanis Salwan Mobidin, Rossilawati Sulaiman, Zarina Shukur and Noorazean Mohd Ali \\ Center for Cyber Security, Faculty of Information Science and Technology, \\ Universiti Kebangsaan Malaysia, 43600, UKM Bangi, Selangor, Malaysia
}

Article history

Received: 28-08-2019

Revised: 21-11-2019

Accepted: 03-12-2019

Corresponding Author:

Rossilawati Sulaiman,

Center for Cyber Security,

Faculty of Information Science and Technology, Universiti

Kebangsaan Malaysia, 43600,

UKM Bangi, Selangor,

Malaysia

Email: rossilawati@ukm.edu.my

\begin{abstract}
There is an alarming amount of frozen and unclaimed assets in Malaysia. Among the factors that contribute to this situation is the failure of the decedent to leave a will to the heirs of the estate or to leave the important documents necessary to initiate the distribution of the estate. This lack of preparation will inimitably put the heirs in a difficult position because they will have to spend their time and money to search and collect all related information and documentation related to the estate to assist them in liquefying and distributing the assets. With the advancement of information technology, there are information systems that had been built to manage and plan the estate of individuals. However, these systems have limitations and are unsuitable to be implemented in Malaysia because of different laws and procedures. Therefore, this paper proposes a personal legacy information system that will allow the owner to manage information such as assets, debts, wills and personal secrets, in a single platform. In addition, the owner can keep related documents to the information that are required for asset planning and distribution, especially in the Malaysian context. The owner can appoint a trustee(s) through the system and all information will be released by the system to the trustee when the owner dies. By applying encrypted communication, the legacy data will be kept secure. Static analysis is described at the requirement level for specifying the functional requirements of the system, using Z Specification. We hope that the proposed system will help mitigate the issues surrounding the problem of frozen and unclaimed assets.
\end{abstract}

Keywords: Personal Legacy Information, Information Management System, Assets, Debts, Personal Secrets, Inheritance, Z Specification

\section{Introduction}

"Legacy" can be defined as what is left to a person in a will (Legacy, 2017). When someone dies, he/she left his/her assets, debts and personal secrets, which in this paper will be referred to as legacy information. In Malaysia, the amount of frozen and unclaimed assets belonging to the Muslim population is increasing (Aziz, 2017; Mujani et al., 2011). In Muslim countries, it is more challenging to manage these assets because Islamic laws must be adhered to. Existing Islamic laws offer holistic solutions, however, the implementations have legislative constraints (Ahmad et al., 2017; 2018). There are many factors that can contribute to the frozen and unclaimed assets. One of them is due to the lack of knowledge in comprehensive estate planning among the citizens (Rashid and Yaakub, 2015). This factor may lead to the delay and failure in distributing the legacy.
One of the more serious issue that occurs is the case concerning the distribution of land properties. On many occasions, land properties left by the decedent are without proper land transfer instructions to the heirs. In some cases, the decedent had died for a long time and the heirs did not even know about the existence of the legacy. This resulted in a great loss to the heirs. Mat Zuki (2019) reported that the issue of abandoned land comprising a total of RM66 billion worth of inheritance land titles among Muslims in Malaysia still have not been settled. A growing concern among the Malays (the largest ethnic group in Malaysia) whose reserve lands amounting to RM38 billion in market value, have not been settled as a consequence of the delay and failure in distributing the legacy (Said, 2006).

Another common issue is that the heirs do not have a complete documentation or clear instructions to follow, 
in administrating the estate left by the decedent. There are situations where the heirs have faced too many problems to proceed with the distribution process and subsequently abandoned the process half way. Properties whose ownership is not clear and is subjected to multiple claims of ownership may also be the source of delay in the legacy distribution process. According to the Director General of Department of Lands and Mines (DLM, 2019), the heir who applies for the legacy distribution will have to cancel the first application and initiates a new application, in case of incomplete information. This process may delay the distribution of the legacy and add additional costs.

Early planning to legacy distribution can avoid the event of additional legacy appear in the middle of the distribution process. Having a complete document about the assets of the decedent can avoid delay in the distribution process (Ahmad Rodzy, 2016). The ownership documents of the assets must be provided to manage the legacy distribution. A police report needs to be lodged in case of losing a document. In case of lands, to ensure there is no assets left behind, the heirs can go to the nearby Land Offices to conduct a registered land title search (SDLM, 2017).

In Malaysia, the better way to avoid the issue of frozen and unclaimed assets is by leaving behind a will (Wasiyyah). As reported by a well-known private trustee organization As-Salihin (2017), in the case of the existence of a will, it takes only 18 months to settle the process compared to five years if one dies intestate (without a will).

In certain situations, when the management of the legacy information becomes complex, the heirs to the estate will appoint lawyers or any trustee company to assist them in identifying the information before the estate distribution process can take place.

With the advancement of information technology, there are systems that had been developed to manage the decedent's legacy on the web (Bahri et al., 2015). According to Waugh (2012), most people nowadays have many online accounts and the tendency to forget the details of the login credentials is high. Thus, it leaves the problem of managing the online accounts more challenging. This issue gives rise to the birth of many companies that are charging fees to handle online legacy (Peoples and Hetherington, 2015). However, these systems are mostly dedicated to managing Social Network Sites (SNS) of the decedents and left other legacy information aside.

Many researches on managing the legacy information have been done, but not suitable to be implemented in Malaysia as a result of different laws and procedures. For instance, there are systems that require the use of digital signatures as well as digital death certificates such as presented in (Chien and Lin, 2019; Chen et al., 2011), which currently cannot be practiced in Malaysia.
Currently, the digital signature law implemented in Malaysia were created to enhance e-commerce activities as well as e-government activities, such as ecourt and e-filling. Another important issue is Death Certificates, which is among the main requirement to manage the asset distribution. Death certificates in Malaysia is still in a hard copy form. This certificate should be retrieved manually at the National Registration Department (NRD, 2019). The certificate is a secure document which requires the heir to collect it person. Therefore, the issuance of the certificate online has not yet been implemented because it is tied to a security policy. The certificate can only be printed through the computing system at NRD.

With regards to the distribution of the Muslims' estates, there are existing systems developed by the local researchers, with the intention to ease the problem of delay in legacy distribution. As reported by Hussain (2007), the $e$-Faraid and $e$-Syariah systems had played an important role to ease the legacy distribution process and cut the processing time. However, the systems presented problems related to the accuracy of the solution from calculations given to the heirs in dividing the assets (Noordin et al., 2012). Although the systems had shown a decrease in backlogs and had shorten the time taken to settle a trial (Muhammad, 2009), the amount of unclaimed assets is still high (Ahmad and Laluddin, 2010).

So far, there is one similar system for legacy management system, which is patented and proposed by Fallon (2002), which are a designed to collect a user's legacy information. This includes personal information, financial and legal information, as well as medical information. However, the system is offered to organizations such as the banks, or other financial institutions and law firms. The user can name his/her trusted individuals, or to appoint these organizations as a trustee. From here, the organizations may contact the trusted individuals, or alternatively, the trusted individuals identify themselves to the organization and if the identities are verified, the individuals are granted access to the user's personal legacy information.

In summary, there are many issues that resulted in the unclaimed assets and delays in the legacy asset distributions in Malaysia. In order to navigate this issue, in this paper, we introduce the Personal Legacy Information Management System, which in short will be referred to as PLISMA. PLISMA focuses on providing a platform for the owner of the legacy information to manage and keep any legacy information and documentation concerning the assets, debts, or will, that are relevant and necessary to expedite the administration of the estate upon the demise of the user. PLISMA enables the owner of the legacy information to leave instructions or general requirements to the heirs or trustees for asset distribution and debt settlement process according to the current laws in Malaysia. 
This paper is structured as follows: In the second section, we explain current business process for Islamic asset management in Malaysia. In the third section, we state some scenarios that PLISMA can support; while in the fourth section, we discuss further on our proposed system requirement and model the functional requirement specification using Z Specification (Shukur et al., 1999). We conclude the paper in section five.

\section{Background Study}

\section{Current Business Process for Islamic Asset Management in Malaysia}

Planning on how the legacy will be managed is important. Legacy planning is the activity of making early preparation on how the legacy are going to be administered and distributed once the owner of the legacy dies. Legacy planning is done during the lifetime of the asset owner. The owner will decide on what and who will inherit the legacy. Planning is important in order to ensure all the assets can benefit the living heirs. In the context of Malaysia, where Muslims made up the majority of the population, there are certain obligations that must be carried out following the demise of a Muslim. The first obligation is to clear all funeral expenses. Next, is to clear all the debts to God and mankind. Recorded debts such as income tax, real property gain tax and others are easy to resolve than unrecorded debts (Rasban and Mohd, 2010). Unrecorded debts can be debt to God which are difficult to resolve. Kaffarah, Hajj and Zakat are example of debts to God.

Kaffarah means an act that can eradicate sin. Examples of Kaffarah are alms and fasting with certain conditions. Some types of Kaffarah that are imposed are Kaffarah for marital intercourse in the month of Ramadan and Kaffarah for ones that are not performing Qada' fasting (making up a missed fast until the next Ramadan) (JAWHAR, 2017).

Hajj is one of the five pillars of Islam. Muslim adults that are financially capable and physically and mentally healthy are mandatory to perform Hajj at least once in their lifetime (Al-Hashedi et al., 2013). If someone is not able to perform the Hajj, or they die before being able to fulfil their $H a j j$, their heirs are encouraged to perform Hajj on their behalf (Hajj-al-badal), just as they would pay a debt on their behalf.

The payment of Zakat is a compulsory form of worship. Zakat is a form of charity that is obligatory upon a person when the conditions imposed are met. If someone is not able to pay for their Zakat upon his lifetime, their heirs are advisable to pay for them.

In Islam, there are a number of asset distribution instruments such as: Faraid, Wasiyyah, Hibah (gift), Waqf, jointly acquired property and others. The Islamic inheritance law is known as Faraid. This branch of
Islamic jurisprudence determines the heirs and the entitlements to the estates. The inheritance occurs through marriage, consanguinity and emancipation of slaves. However, slavery has been abolished in Islam. Faraid is executed only after all the funeral expenses and debts have been subtracted from the decedent's legacy.

In Islam, will is called Wasiyyah. The implementation of Wasiyyah is only effective after the death of the testator. In Islam, will is only allocated for non-heirs and the will must not be more than one third of the total estate value. However, non-heirs can get more if a permission is obtained from other heirs. Parents of adopted children are encouraged to do Wasiyyah as adopted children are not entitled for Faraid.

Gift or Hibah is the transfer of assets that takes place when the donor and receiver is still alive. Usually, people left behind Hibah for the person they loved most. Waqf is religious endowment. Waqf is an act of charity. People would assign some of their assets for the purpose of charitable use. Waqf can be in the form of cash or assets.

Jointly acquired property is the act of declaring the assets obtain by married couples throughout their married life. The assets include the savings of the husband and wife, insurances and investments, or any form of assets acquired during their marriage. These assets must be segregated from the decedent's assets and given to the surviving spouse. Due to some conflicts between civil laws and Islamic laws, there are cases of difficulties of distributing inheritance for spouses that were Muslim converts or non-Malays, which are related to the claims of property after the death of either spouse (Mohd Kusrin et al., 2012; Wan Hassan et al., 2012). For example, under the Malay Reserve Enactment, land in a Malay Reservation Area cannot be transferred to the non-Malays, Therefore, if a Malay husband has a piece of land and is married to a non-Malay wife, when the husband dies, the wife is not entitled to inherit the land. However, this is conflicting with the Islamic law, where the wife (regardless of the race) is entitled for the inheritance.

The management of decedent's assets in Malaysia are as follows:

a. High Court: Manage testate assets (with a will) with the amount of movable and immovable asset of more than RM 2 million (PA Act, 1959)

b. DLM: Manage intestate assets (without a will) with the amount of movable and immovable asset of RM 2 million and below (SED Act, 1955)

c. AmanahRaya (2019): Manage the intestate asset of movable asset of RM 2 million and below (PTC Act, 1995)

d. Sharia Court: Provide Faraid Certificate to High Court, DLM and AmanahRaya (AIL Act, 1993) 
Table 1: Items required for management of legacy

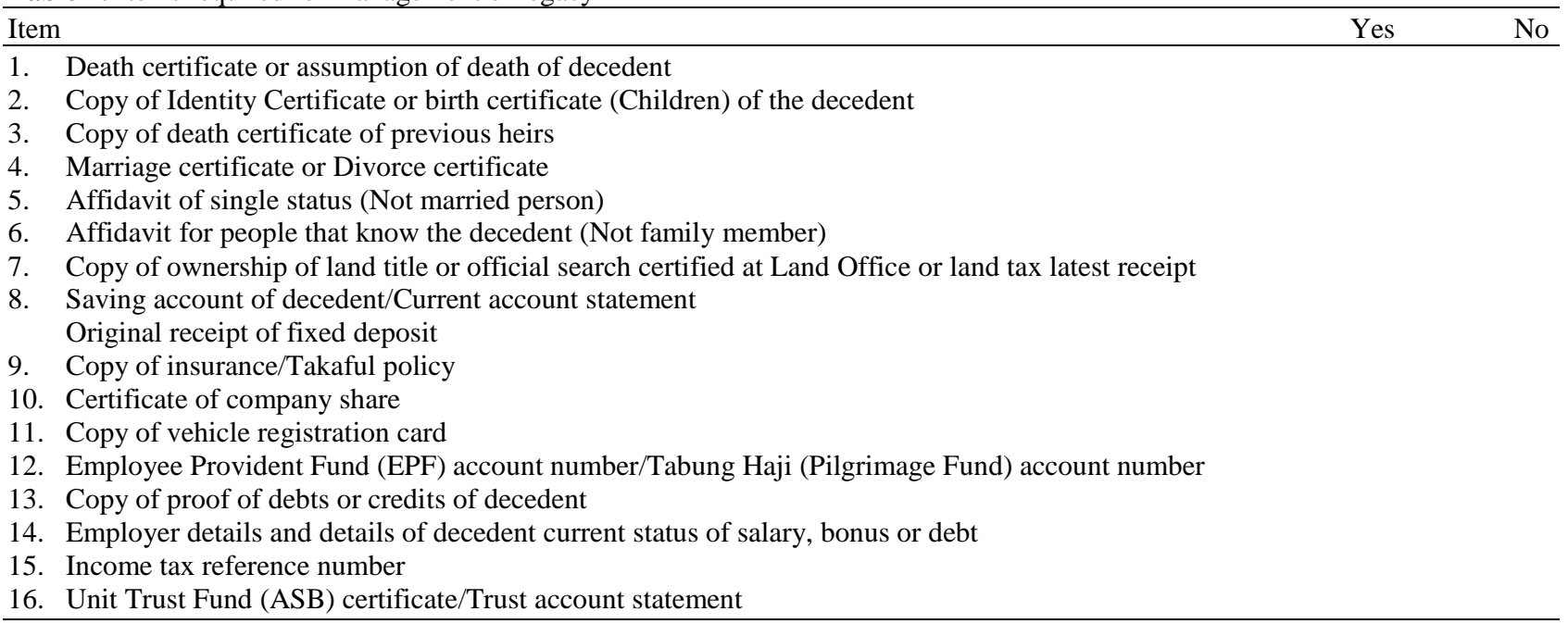

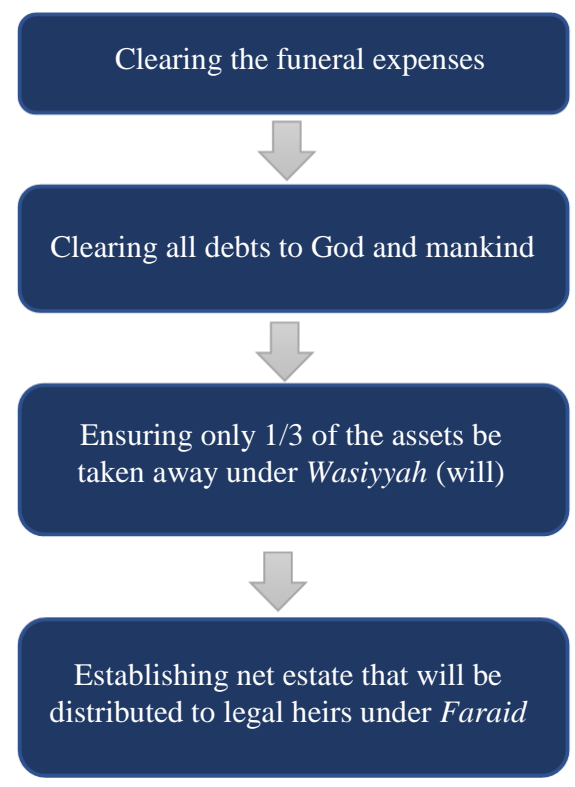

Fig. 1: The Sharia asset distribution process

Figure 1 shows the steps that Muslims has to go through before the assets can be distributed (An-Nawawi, 2019). After all debts has been cleared, then only Wassiyah or will is inspected, followed by distributing what is left on the assets.

Table 1, which is proposed by Bahari (2012), is a checklist of required items, which can be used by an heir or a trustee, before starting the process of distributing the legacy in Malaysia.

\section{Personal Secret and Digital Asset as Legacy Information}

Besides the physical assets, there are instances whereby the decedent had kept certain private or secret information which are not made known until they die. Some of these secrets can have grave consequences to the heirs of the decedent. For example, in the case of adopted children, some Muslims prefer changing their biological father's name to the name of the adoptive father, which may cause some confusion when it comes to the administration of the inheritance. Since adopted children are not entitled to the inheritance unless stipulated in a will left by the adopted parents, the discovery of the fact that they are not the biological children of the decedent will lead to disputes among the heirs.

Another example is the act of secretly practicing polygamy. In Malaysia, men usually have to go through some difficult procedures to be able to practice polygamy (Kamel, 2013). This leads to cases where they prefer to keep their marriage a secret until the day they die. Polygamous marriages that take place without the consent of the relevant authorities in Malaysia may cause certain problems if the marriage is found invalid by the Sharia court. This marriage cannot be registered and, any claim made to the court predominantly concerning inheritance will not be entertained (Abdullah, 2007). Furthermore, since the first wife does not know about the polygamy, she might think that she alone is entitled to the inheritance allocated to surviving wives under Faraid. The other wives in the polygamous marriage will then face difficulties in claiming their rights to the inheritance and might have to go through a series of court proceedings.

The number of children out of wedlock in Malaysia is increasing yearly (Md Denim et al., 2019). In Islam, a child born from adultery are only entitled to their mother's inheritance. However, there are cases whereby the parents keep the child's status a secret hence allowing the child to claim his or her inheritance as a normal heir. This action is against the rule of Islamic inheritance law because the child has taken the rightful heirs' rights without their knowledge. 
Another secret information is the use of SNS such as Facebook, Instagram, Twitter and Google products for business purposes. Problems will arise when the owner of the online shop dies because then online shop cannot operate unless the online sellers had given his/her login credentials to a trusted person. Even though this might violate the terms and conditions of the SNS, it is important to make sure that none of the customers of the online business are left unmanaged (Saizan and Singh, 2018).

\section{Legacy Information: Possible Scenarios}

In this section, examples of possible scenarios related to debts, assets and personal secrets are presented. The scenarios state the list of activities the user go through and as a support for the system.

\section{Scenario of Debts to God}

\begin{abstract}
Adam is a successful business man. He owns a huge textiles company. However, he rarely practiced Islam in his life. His family members always remind him to be a pious Muslim. He deliberately eats and drinks during the month of Ramadan even though he is in good health. He also does not want to perform his Umrah and Hajj as he believes he is still young and have plenty of time. Unfortunately, he was involved in a hit and run accident that paralyzed half of his body. He decides to list down his debts to God as he is afraid, that he did not have much time left. He wants to make his life clear of the debts.
\end{abstract}

In this scenario, Adam was so fortunate to be alive after being involved in a tragic accident. To enable Adam to list down the things that he wants to settle, he needs PLISMA to record all the information. Due to his weak body, he decides to do Umrah and Hajj al-Badal (the act of performing Umrah or Hajj on behalf of someone else who have either passed away or terminally ill). He also wants to pay for his Qada' (make up the fast) and Kaffarah (compensation that Muslim should pay for deliberately miss or break a fast during Ramadan without a valid excuse).

\section{Scenario of having a secret polygamous marriage}

Harris has his second marriage in Thailand as he is not confident that his application for polygamy will be approved by the local Sharia court. He also does not wish for his first wife to know about his intention to take a second wife. He does not register his marriage to his second wife in Malaysia. He has decided to keep his second marriage a secret in order to maintain harmony between him and his first wife. He wants to do assets planning as a precaution if he dies. He wants to keep the details of his second wife and their child. He also does the same with his first wife and the rest of his children as he does not want all his wives to be in dispute when he dies.

The scenario is about declaring a secret polygamous marriage. Harris is afraid that his family will be in trouble if the secret is revealed during his lifetime. He wants to tell the secret to them when he dies. PLISMA can be a solution for him. He can leave in peace if he has already done the asset planning. The welfare of the second wife and child will also be maintained.

\section{Scenario of Having Many Assets}

\begin{abstract}
Sofea inherits many pieces of lands and assets from her rich father. Because of the location, she rarely goes to see the lands and entrust Adam to manage the lands. She made an official agreement with Adam to let her family take charge of the land if she dies. Some of the assets, she has already sold to her friends, but the transfer is still in process. In addition, Sofea also wants her heirs to know about the income she generates from her online shop. She owns an online shop selling blouses. She wants her family to know about these assets after she dies. She needs a system that can help her record all the lands and assets so as not to leave her heirs in trouble in the future.
\end{abstract}

This scenario shows Sofea, which needs the aid of PLISMA to inform her family about her legacy information. She can upload the instructions on what to do, in case she died. She would feel at ease if she is able to tell her heirs about the legacy as not to leave the legacy unmanaged. By having the legacy kept in a system, she can update the legacy information from time to time and upload the scanned documents of the legacy in the system. She can also leave her username and password of her SNS account for her online business to her heirs.

\section{Legacy Information System Requirements}

Based on the business process and scenarios discussed earlier, this section proposes the architecture and requirements for PLISMA. The specification is prepared using MacTex (http://www.tug.org/mactex/) and type-checked using Z/EVES (Saaltink, 1997). The requirements of PLISMA are obtained from literature review as well as interview sessions from various parties such as banking sectors and private trustee organizations. 


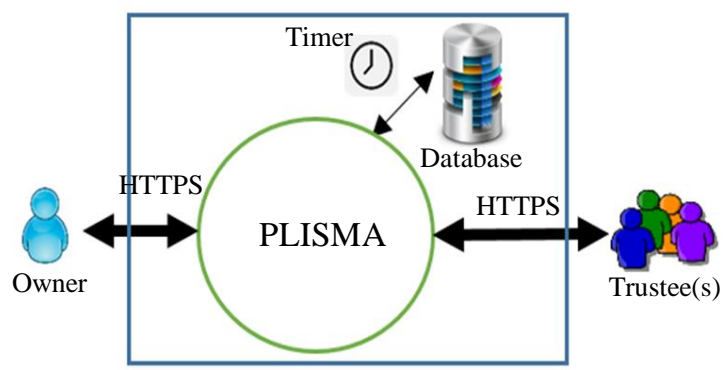

Fig. 2: Architecture of PLISMA

\section{The Architecture of PLISMA}

The components PLISMA include users, a timer and the database such as shown in Fig. 2. Each of the component hold a different function:

1. User: User plays the biggest role in the system. In this paper, the users involved are Owner and Trustee(s).

- Owner: owns the legacy information. Owner also appoints Trustee. Owner can set the time to trigger the legacy information to be revealed to the Trustee.

- Trustee: the most trusted person chosen to manage the legacy information once the Owner dies. They can make a request to Owner to view the data during the lifetime of the Owner and notify the Owner over a matter that is related to the legacy information.

2. Timer: Owner uses a timer to set the duration of the time before Trustee(s) can unlock the information.

3. Database: The database is the place where all the legacy information is kept.

4. PLISMA system: PLISMA enables Owner to list down all the legacy information they want to keep together with the scanned copies of the authentic documents, uploaded to the system. The information in PLISMA can be anything that can be inherited and considered as legacy, such as any movable assets or immovable assets, including any Islamic disposal assets documents such as Wasiyyah (Will), Hibah, Waqf, jointly acquired property and personal secrets. Examples of items in PLISMA can be like the following (this list of items can be added or removed in the system as necessary):
(a) Instruction for asset distribution
(b) Personal Secret
(c) Marriage certificate
(d) Copy of ownership of land title
(e) Bank account numbers
(f) Insurance policy
(g) Company share certificate
(h) EPF and Pilgrimage Fund account numbers
(i) Wassiyah (Will)
(j) Hibah
(k) Waqf
(l) Online credentials
(m) Salary information
(n) Unit Trust Fund
(o) Debts
(p) Income tax

If we revisit the Legacy Information: Possible Scenario section and refer to scenario of Adam, Harris and Sofea, each of them can have a list of items from (a) to (p), or maybe less or more depending on their needs. However, they can emphasize on certain items like the following:

- Adam's scenario can emphasize on item (b) Personal Secret, which is debts to God:

i. Days of missed fasting in Ramadhan

ii. Amount of Kafarah to pay

iii. The name of the person to perform Umrah and Hajj al-Badal for him, with an amount of allocated money to this person.

- Harris's scenario can emphasize on items (a) Instruction for asset distribution, (b) Personal Secret and (c) Marriage:

(a) Instruction for asset distribution

(b) Personal secret:

- Describe the second marriage, the name of the wife and the name of the child

- Asset planning for all family members

(c) Marriage certificate:

- $\quad$ first marriage

- $\quad$ second marriage

- Sofea's scenario can emphasize on items:
(a) Instruction for asset distribution
(b) Copy of ownership of land title
(c) Company share certificate
(d) Bank account numbers
(e) Online credentials of her online shop

\section{Functional Requirements of PLISMA}

Figure 3 shows the use case diagram for PLISMA where the actors are Owner and Trustee(s). In requirement modelling, a use case can represent the interaction between users and the information system. In a use case, users become the actors, with specific roles that describe their interactions with the system. There are several use cases and actors involved in PLISMA. 


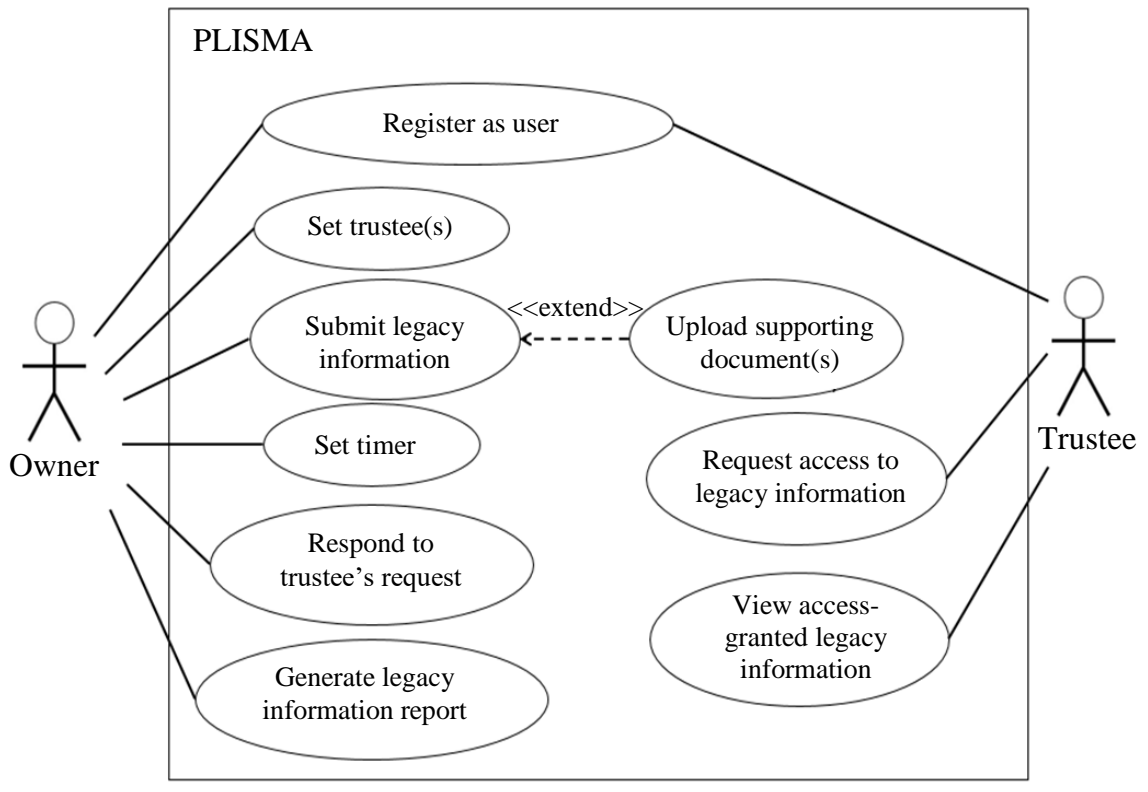

Fig. 3: Functional requirements of PLISMA

Owner starts with the online registration. Then, the system sends a confirmation email to Owner. Owner is given a temporary username and password. He/she is advised to change the username and password to continue using the system. Owner has the options to fill in the legacy information, upload documents, appoint Trustee(s) and set the timer. Owner also has the power to deny any access from Trustee(s) and get any notification from Trustee(s).

Once a Trustee had been appointed, system contacts the Trustee to get feedbacks. Within two days' time, if the Trustee fails to response, the appointed Trustee is considered invalid and Owner has to find another Trustee. Owner can set a reasonable time to trigger the event of his/her death, to indicate that he/she can be pronounce dead.

To check for the active status of Owner, the system will notify Owner to log into the system in every two weeks (the duration can be set by Owner). Two weeks' duration is chosen as the default value, as we consider it a reasonable time. There are cases in Malaysia that can go up to four months and some cases go unresolved (Ahmad et al., 2017). However, Owner can change this value accordingly.

Within two weeks' time, if the system fails to get any response from Owner, the system will contact Trustee, asking for confirmation. If the response is positive, the system will enable the Trustee to gain access to the legacy information saved in the system with the condition they provide the authentic death certificate serial number. The process of verifying the authenticity of the death certificate is outside the scope of PLISMA. In practice, this death certificate is obtained through NRD, only after the heirs produce a doctor's report and a police report. NRD can produce the death certificate many times, upon request by the heirs. Therefore, in a case where the serial number produced by Trustee is faked and although Trustee can access the information, Trustee still cannot proceed with the distribution process, as the death certificate can always be produced and checked by other parties. PLISMA does not interface with any other authorities' systems so far, such as NRD, although we agree that, that will be the best case scenario.

A Trustee on the other hand can accept or reject the invitation through an email. If he/she agrees on being a Trustee, he/she can make a request to Owner to view the legacy information. If the requests are granted, then they can view the information. However, if the request is denied, any attempt made to view the information will be notified to Owner. Owner can decide to remove Trustee from the system. Trustee is also able to send notification to the Owner.

Trustee can see any update done by the Owner, but they are prevented from seeing the content of the data being uploaded into the system. Trustee can only view the information once the system had notified the death of the Owner.

\section{Non-functional Requirements of PLISMA}

Since legacy data is a sensitive information, security aspects should be considered. In order to ensure the legacy information did not fall to the wrong hands, user authentication is used by using strong username and password. Users of the system must log into the system using their username and password. In addition, every page in the system will use a secure, encrypted transmission of SSL/HTTPS. SSL is a secure protocol to encrypt communications of data to and from the database, which can avoid eavesdropping by unauthorized users. 


\section{Z Specification for PLISMA Functional Requirements}

In this section, we describe the static analysis at the requirement level and we use $\mathrm{Z}$ Specification in order to specify the functional requirement specifications and explain the formal analysis.

The following LegacySystem schema defines the states of PLISMA that has ownerList and trusteeList, which are lists of Owner and Trustee; legacyInfo which indicates any legacy information entered by the Owner; timerList, which indicates the Timer and trusteeAccess; which indicates whether the Trustee can access the legacy information:

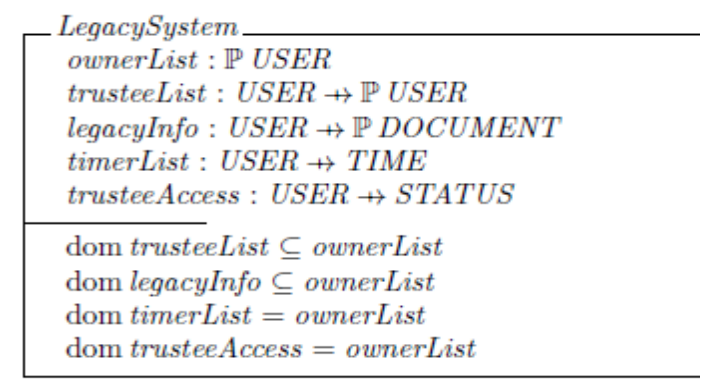

An Owner can have many Trustee and Legacy Information $(\mathbb{P})$. Timer and Access status will be set by default when a new Owner is registering to the system.

The next schema, InitLegacySystem shows the initial state of LegacySystem, where initially there are no records of Owner, Trustee and legacy information:

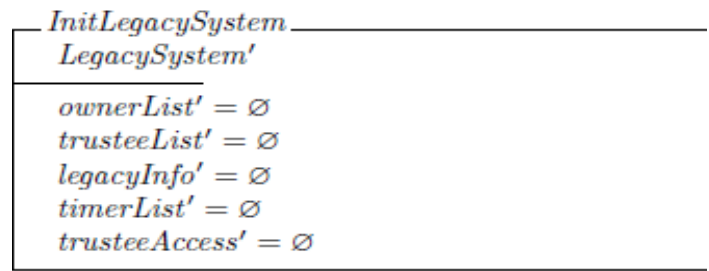

OwnerRegistration schema describes the registration action of Owner into PLISMA. A new Owner must not be in the ownerList. The Owner must set a default time. The trusteeAccess must be set as "passive", where there is no Trustee appointed yet:

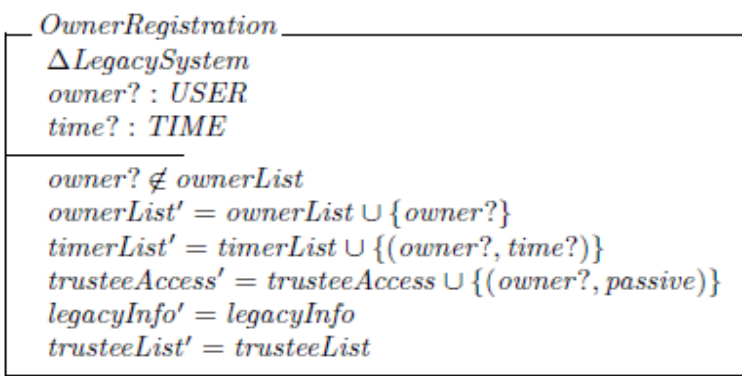

Actions that can be triggered by Owner of the legacy are SetTrustee, SetTimer, ResetAcess and SubmitLegacyInfo, described in the following schemas. SetTrustee and SetTimer let Owner assigns Trustee(s) and set the default timer:

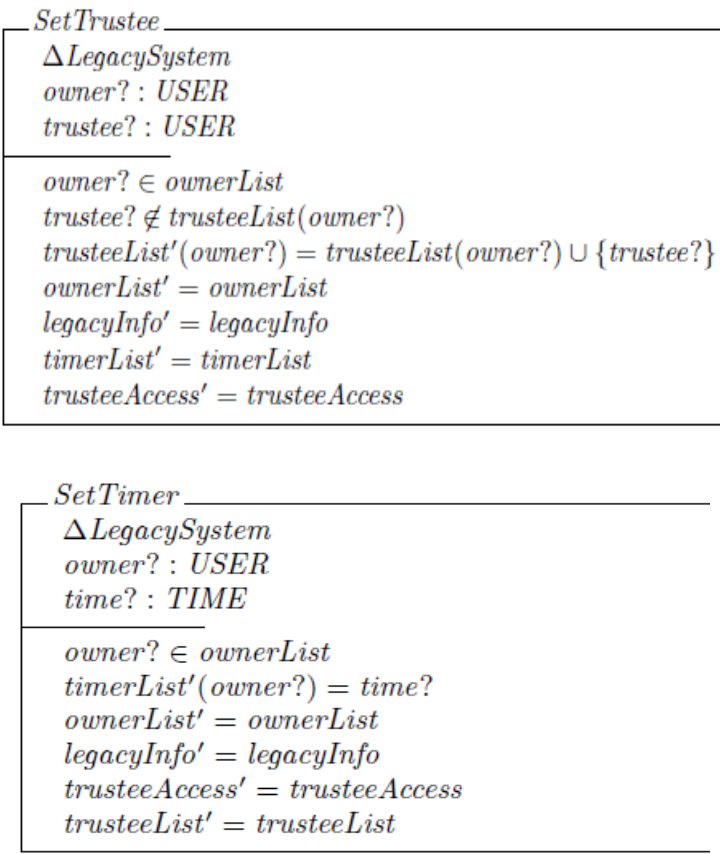

ResetAccess functions like a toggle or switch to change the trusteeAccess from passive to active and vice versa:

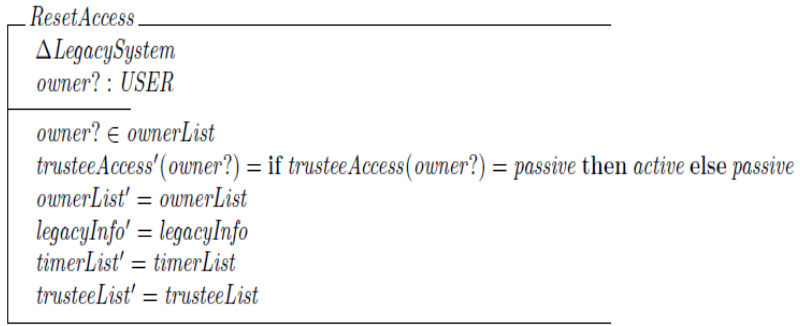

SubmitLegacyInfo schema allows Owner to upload any documents related to the legacy information. This is an abstract specificaion, where we do not differentiate the types of legacy information:

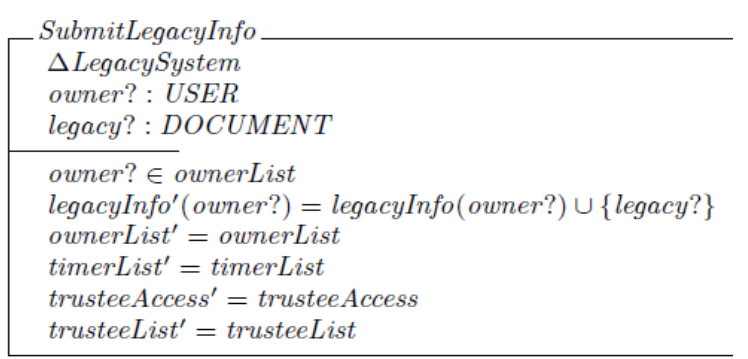


Next, GeneratelegacyInfo allows Owner to generate the legacy report, hence no access permission need to be checked. This operation returns the list of legacy documents of a particular Owner. NotifyOwner let PLISMA check the status of the Owner, to determine whether the Owner is still alive:

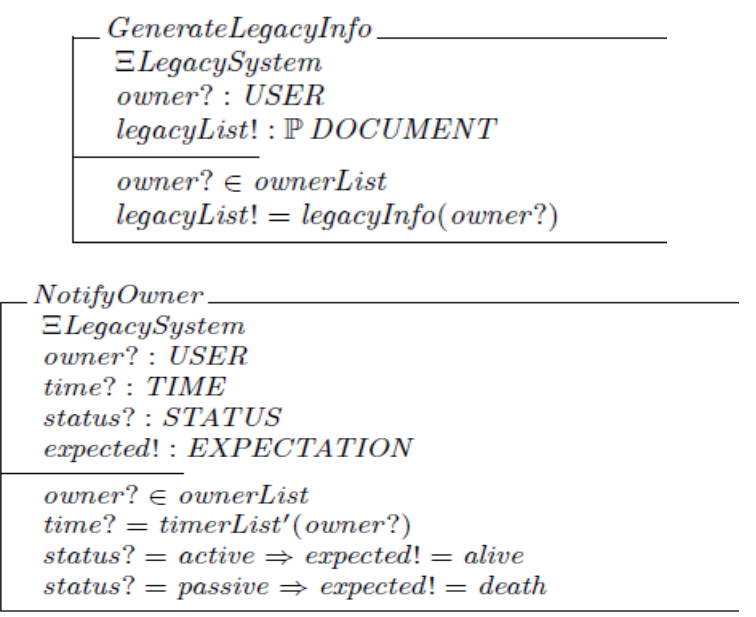

The next schemas RequestLegacyInfo and ViewAccess are the actions that can be triggered by Trustee. Trustee can be a trustee of more than one Owner. Therefore, a Trustee must specify which legacy information of which Owner that he/she requested. Also, Trustee must be granted an access to the legacy information:
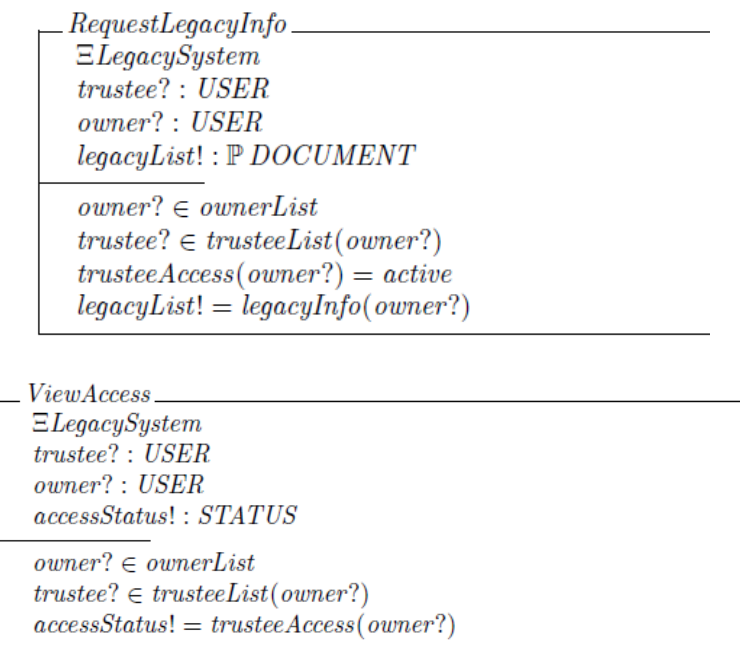

\section{Analysis of legacy System Specification}

Saaltink (1997) suggested five ways that Z/Eves can be used to analyse $\mathrm{Z}$ specification: Syntax and type checking, domain checking, schema expansion, precondition calculation and general theorem proving. Whereas in (Shukur et al., 2005) they follow Diller (1994), which stated that there are three stages that can be proven in $\mathrm{Z}$ specification; initial state theorem proving, pre-condition calculation and properties proving.

In this section, we have prepared several theorems related to the specification, where the result of the first two are shown. Also, we have successfully carried out the syntax and type checking of the specification, as shown in Fig. 4.

\section{Initial State Theorem}

It is important to show that there exists at least one state that is satisfied by the system and it is stated in the following Initial State Theorem:

$$
\begin{aligned}
& \text { theorem InitLegacySystemOK } \\
& \quad \exists \text { LegacySystem } \bullet \text { InitLegacySystem }
\end{aligned}
$$

After reducing (using 'prove by reduce' command), Z/EVES produces the formula true; LegacySystem and InitLegacySystem were expanded, the one-point rule was applied and some rewrite rules of the Toolkit were applied Fig. 5.

\section{Pre-condition Calculation}

Normally, registration is done once, hence we can use pre-condition calculation to prove this property. The similar command, 'prove by reduce' is used and the result is as shown in Fig. 6. The rest of the following theorems are prepared to be proved:

$$
\begin{aligned}
& \text { theorem RegistrationOnce } \\
& \forall \text { OwnerRegistration } \bullet \text { owner? } \notin \text { ownerList } \Rightarrow \text { pre OwnerRegistration }
\end{aligned}
$$

Only existing owner can register his/her trustee:

$$
\begin{aligned}
& \text { theorem ValidOwner } \\
& \quad \forall \text { SetTrustee } \bullet \text { owner } ? \notin \text { ownerList } \Rightarrow \text { pre SetTrustee }
\end{aligned}
$$

Similar theorem is used to prove only valid owner can do these operations: SetTime, ResetAccess, SubmitLegacyInfo and GenerateLegacyInfo. Only related Trustee(s) can request legacy information and view access mode. An example of theorem:

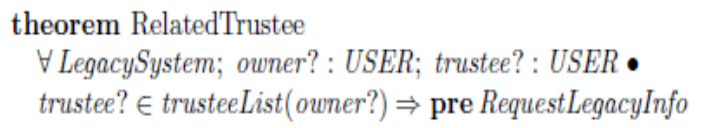

Only related trustee(s) with active access is allowed to request legacy information:

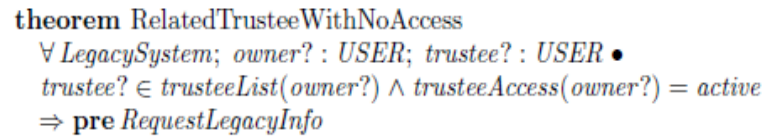




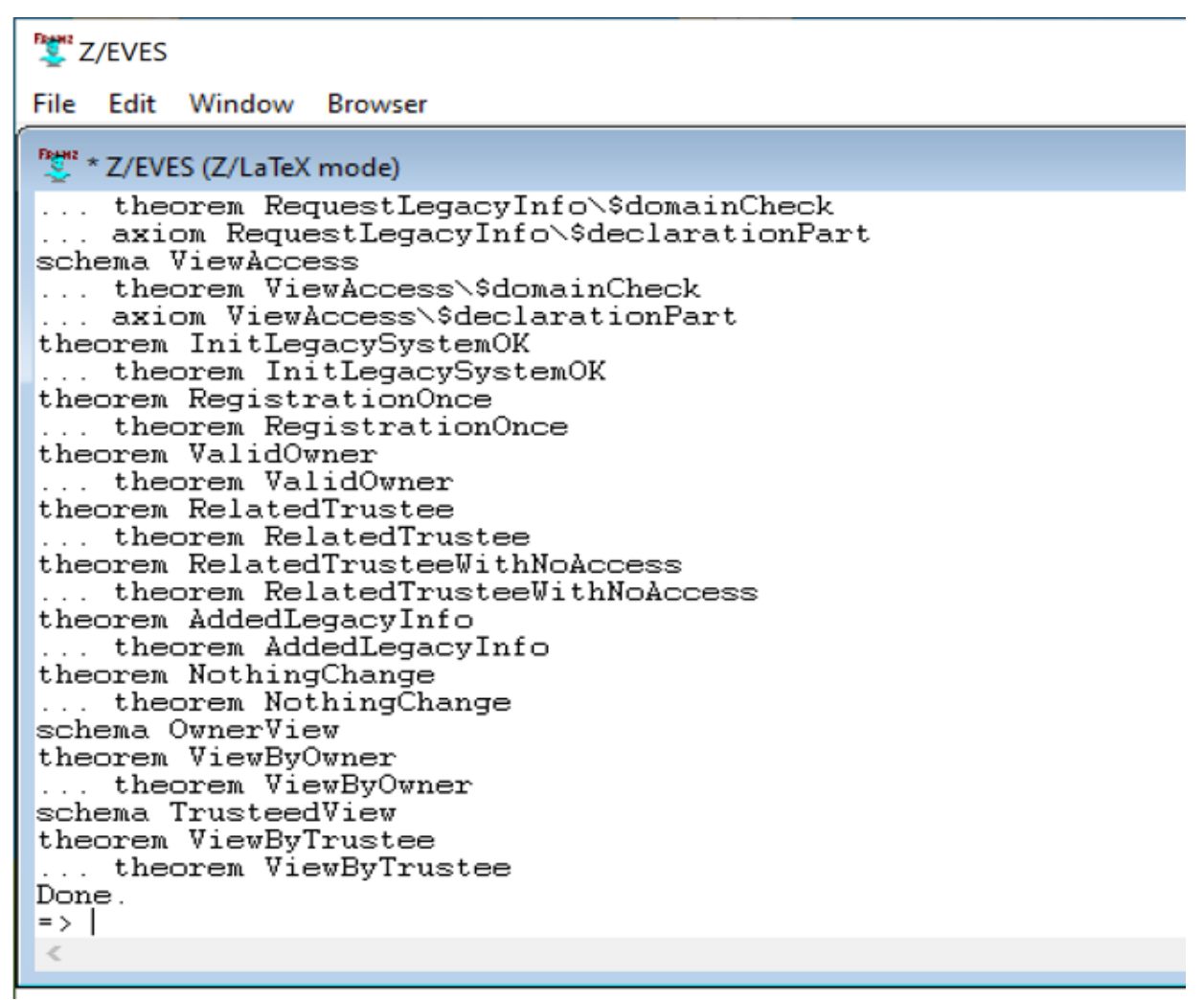

Fig. 4: Screen shot of Z/EVES when reading the LegacyInfo specification

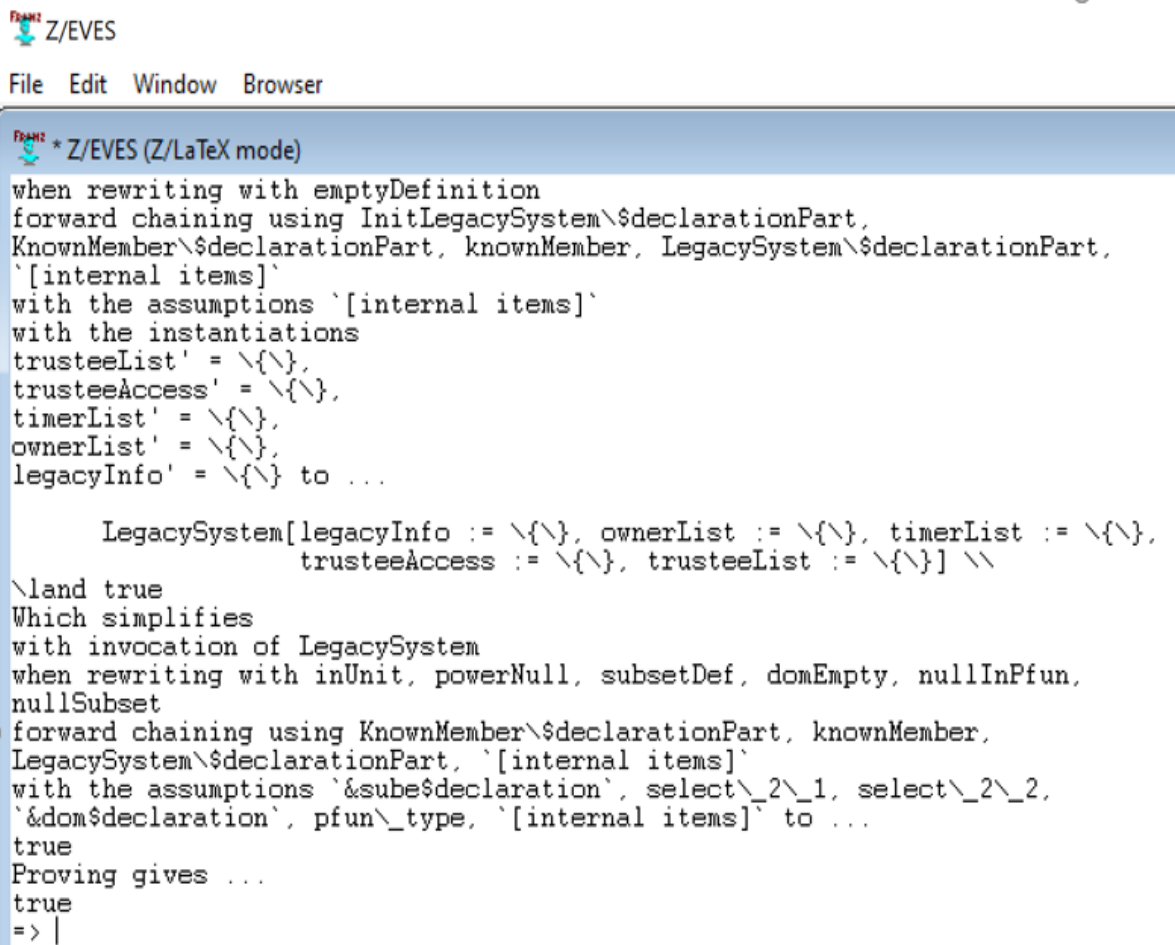

\section{* Z/EVES (Z/LaTeX mode)}

when rewriting with enptyDef inition

forward chaining using InitLegacySystem $\backslash \$ d e c l a r a t i o n P a r t$,

KnownMenber \declarationPart, knownMember, LegacySystem \\$declarationPart,

[ internal itens]

with the assumptions '[internal items]'

with the instantiations

trusteeList ${ }^{\prime}=\backslash\{\backslash\}$.

trusteeAccess' $=\backslash\{\backslash\}$.

timerList ${ }^{\prime}=\backslash\{\backslash\}$,

ownerList ${ }^{\prime}=\backslash\{\backslash\}$

legacyInfo' $=\backslash\{\backslash\}$ to $\ldots$

land true

LegacySystem $[$ legacyInfo $:=\backslash\{\backslash\}$, ownerList $:=\{\backslash\}$, timerList $:=\backslash\{\backslash\}$,

Which simplifies

with invocation of LegacySystem

when rewriting with inUnit, powerNull, subsetDef, domEnpty, nullinPfun,

nullSubset

forward chaining using KnownMenber \\$declarationPart, knownMenber,

LegacySysten\\$declarationPart, '[internal itens]

with the assumptions '\&sube\$declaration', select $\ 2 \backslash 1$, select $\_2 \backslash 2$.

"¿dom\$declaration", pf un`_type, '[internal items]" to ...

true

Proving gives ...

true

$\Rightarrow 1$

Fig. 5: Proving the Initial State Theorem 


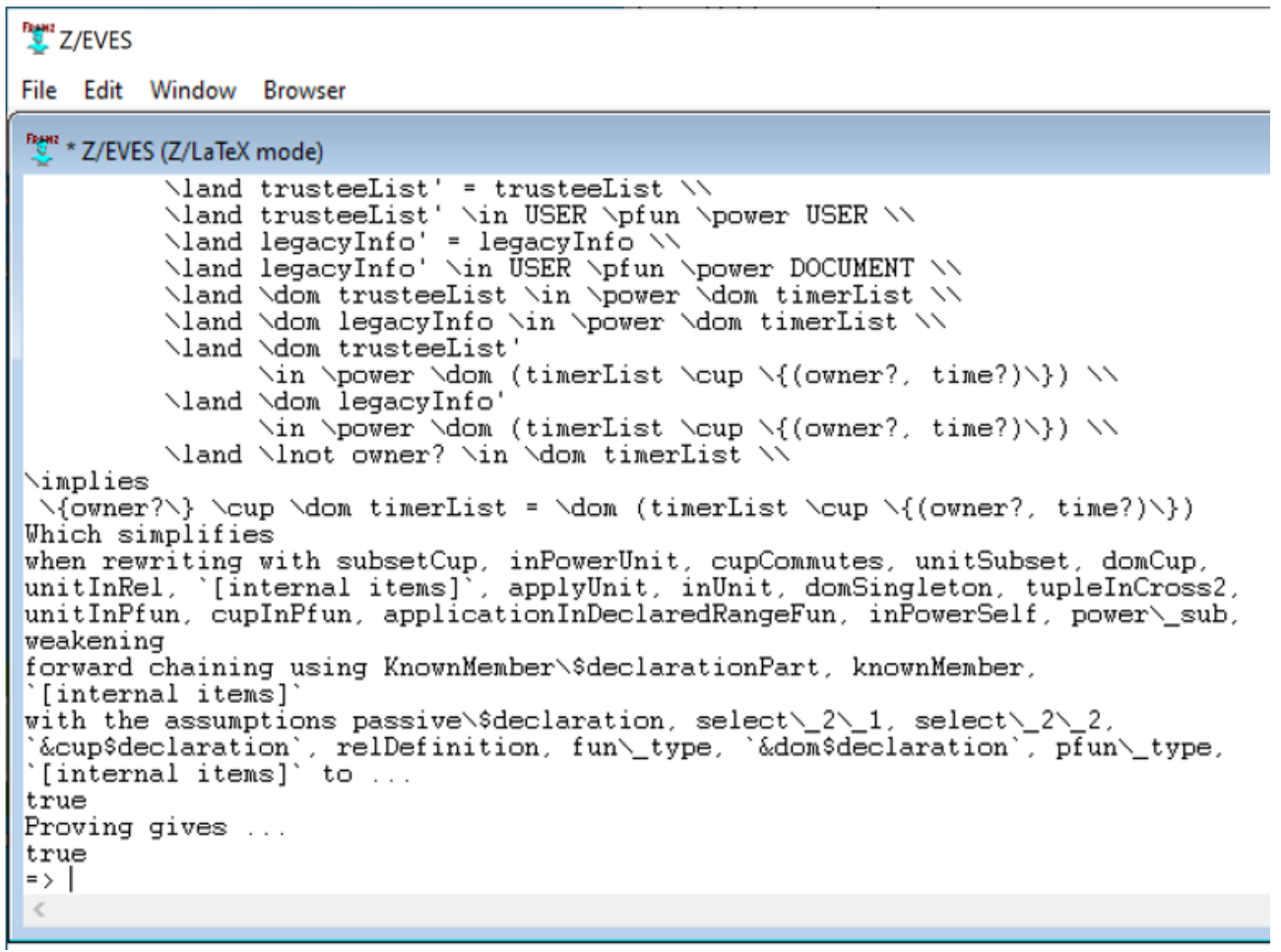

Fig. 6: Proving the theorem RegistrationOnce

\section{Properties Proving}

In this section, we show how two properties are formulated in order to be analysed using theorem proving. Whenever Owner submits new legacy information, it will be added into the existing legacyInfo:

theorem AddedLegacyInfo

SubmitLegacyInfo $\Rightarrow$ legacyInfo $($ owner $)=$ legacyInfo(owner? $) \cup\{$ legacy? $\}$

A Trustee cannot change any information in LegacySystem:

theorem NothingChange

RequestLegacyInfo $\Rightarrow$ ELegacySystem

OwnerView $\hat{=}$ OwnerRegistration 9 SubmitLegacyInfo 9 SubmitLegacyInfo ¡ GenerateLegacyInfo

All recorded legacy information by a valid Owner can be viewed by the Owner:

theorem ViewByOwner

OwnerView $\Rightarrow$ legacyList $!=\{$ legacy, legacy? $\}$

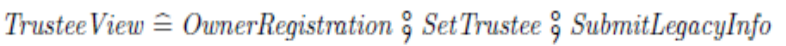

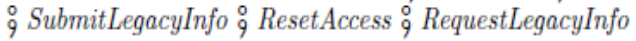

All recorded legacy information by a valid Trustee can be viewed by the Trustee: theorem ViewByTrustee

TrusteeView $\Rightarrow$ legacyList $!=\{$ legacy $?$, legacy $?\}$

\section{Conclusion}

In this paper, we study the issues surrounding asset management in Malaysia especially for Muslims and determine the potential reasons that lead to a high amount of frozen and unclaimed assets in Malaysia. We suggest a system, PLISMA that can help people record all the important documents of assets, debts and secrets in one place on the web. PLISMA enables users to list down all the important information of assets, debts and personal secrets in a web-based system. Users must appoint trustees in order to entrust their legacy data once they die. Users will have the ability to set a timer for the legacy information to be unlocked and revealed to trustees. Users also can upload the certified documents in the system. After an owner dies, the trustees can download the legacy information. This system offers security measurement which are user authentication and the used of HTTPS. With HTTPS connections, all communications will be encrypted. Thus, any attempt of eavesdropping will be prevented. In the future, we suggest the system to have the collaboration with Malaysian authority body such as National Registration Department (NRD), DLM and Malaysian courts. Our future work will be the evaluation of this system, using Focus Groups, which are (1) the owner of the legacy information and (2) the third parties (DLM), AmanahRaya and private trustee organization). 


\section{Acknowledgement}

This research is supported by Universiti Kebangsaan Malaysia (UKM) under the Faculty of Information Science and Technology (FTSM), as well as Research Funds under the code GGP-2017-078 and PP-FTSM-2019.

\section{Author's Contributions}

Hanis Salwan Mobidin: Designed the early architecture for PLISMA as well as collect all related materials regarding the inheritance laws in Malaysia.

Noorazean Mohd Ali: Provided the functional and non-functional requirements for PLISMA.

Zarina Shukur: Provided the Z Specification and formal analysis for PLISMA.

Rossilawati Sulaiman: Provided thorough revision for an improvement of the manuscript for publication.

\section{Ethics}

The authors declare that there are no ethical issues associated with this research.

\section{References}

Abdullah, R., 2007. Polygamy without the Shariah court's permission in Malaysia: A socio-legal perspective. Malaysian J. Soc. Admin., 4: 11-26.

Ahmad, M.Y. and H. Laluddin, 2010. Pengurusan harta pusaka: Permasalahan sikap masyarakat Islam di Malaysia dan penyelesaiannya menurut perspektif Islam. Shariah Law Reports.

Ahmad, M.Y., E.A. Jamsari, M.H. Safiai, I.A. Ibrahim and B. Mohd Nasir et al., 2017. Issues and challenges of perintah faraid (faraid order) in inheritance distribution for Muslims in Malaysia. Int. Bus. Manage., 11: 1598-1604.

Ahmad, M.Y., M.N. Mohamad, M.Z. Muda, E.A. Jamsari and W.Z. Wan Hassan et al., 2018. Confronting the problem of managing unclaimed inheritance property of Muslims in Malaysia. Int. J. Civil Eng. Technol., 9: 1459-1466.

Ahmad Rodzy, T.H., 2016. Selesai kes harta pusaka dalam tempoh kurang 7 hari. Berita Harian,

AIL Act, 1993. Administration of Islamic Law Act.

Al-Hashedi, A.H., M.R. Mohd Arshad, A.S. Baharuddin and H.H. Mohamed, 2013. RFID applications in Hajj management system. Proceeding of the IEEE International Conference and RFID Technologies and Applications, Sept. 4-5, IEEE Xplore Press, Johor Bahru, Malaysia, pp: 1-6.

DOI: 10.1109/RFID-TA.2013.6694546

AmanahRaya, 2019. https://www.amanahraya.my/
An-Nawawi, A.Z.S., 1996. Minhaj At-talibin (Islamic law of succession). Dar Al-Kutub Al-Ilmiyah, Beirut.

As-Salihin, 2017. As-Salihin Trustee Berhad.

Aziz, I.H., 2017. RM60b harta umat Islam tidak dituntut. New Straits Time Online.

Bahari, A., 2012. Soal Jawab Wasiat Islam Solusi Permasalahan Perwarisan Islam, Telaga Biru Sdn Bhd. 1st Edn., Kuala Lumpur, ISBN-13: 9789673880744.

Bahri, L., B. Carminati and E. Ferrari, 2015. What happens to my online social estate when I am gone? An integrated approach to posthumous online data management. Proceedings of the IEEE 16th International Conference on Information Reuse and Integration, Aug. 13-15, IEEE Xplore Press, San Francisco, CA, pp: 31-38. DOI: $10.1109 /$ IRI.2015.16

Chen, C.L., C.C. Lee, Y.M. Tseng and T.T. Chou, 2011. A private online system for executing wills based on a secret sharing mechanism. J. Security Commun. Networks, 5: 725-737. DOI: 10.1002/sec.367

Chien, H.Y. and R.Y. Lin, 2009. The study of secure ewill system on the internet. J. Inform. Sci. Eng., 25: 877-893.

Diller, A., 1994. Z: An Introduction to Formal Methods. 2nd Edn., John Wiley and Sons, Inc., USA, ISBN-10: 0471939730, pp: 374.

DLM, 2019. Department of Lands and Mines.

Fallon, J., 2001. Systems and methods for a personal, universal, integrated organizer for legacy planning and storage. Patent no: WO2002027628A2.

Hussain, R., 2007. Kelemahan sistem e-Faraid perlu dikemaskini. Berita Harian Online.

JAWHAR, 2017. Department of Awqaf, Zakat and Haj Malaysia (JAWHAR). Kifarah.

Kamel, K.M., 2013. Cara betul untuk poligami.

Legacy, 2017. https://www.lexico.com/en/definition/legacy

Mat Zuki, N., 2019. Hartanah pusaka sukar diwarisi, pemilik harta gagal rancang harta ketika hidup. Sinar Harian.

Md Denim, M.J.A, F.A. Mohd Pilus, M.V. Dass, N.S. Salberi and N.H. Bahudin, 2019. Buang bayi setiap 3 hari.

Mohd Kusrin, Z., M.Z. Muda, H. Laluddin and A.B. Mohammad, 2012. Comment conversion and the conflicts of laws in respect of spouse rights to inheritance in Malaysia. Religion Human Rights, 7: $1-9$.

Muhammad, M.R., 2009. Antecedents of IT alignment in public sector: Case of E-Syariah implementation in Malaysia. Proceedings of the UK Academy for Information Systems Conference, (SCP’ 09), United Kingdom. 
Mujani, W.K., W.M.H. Wan Hussain, N.I. Yaakub and R.A. Rashid, 2011. Constructions of failure ad delay under Islamic estate management. Medwell J., 5: 326-330.

Noordin, N., A. Shuib, M.S. Zainol and M.A. Mohamed Adil, 2012. Review on issues and challenges in Islamic inheritance distribution in Malaysia. OIDA Int. J. Sustainable Dev., 3: 75-86.

DOI: 10.24200 /jonus.vol3iss1pp75-86

NRD, 2019. National Registration Department.

PA Act, 1959. Probate and Administration Act.

Peoples, C. and M. Hetherington, 2015. The cloud afterlife: Managing your digital legacy. Proceedings of the IEEE International Symposium on Technology in Society, Nov. 11-12, IEEE Xplore Press, Ireland, pp: 1-7.

DOI: 10.1109/ISTAS.2015.7439412

PTC Act, 1995. Public Trust Corporation Act.

Rasban, S. and I. Mohd, 2010. Muslim Law in Wealth and Estate Transfer. 1st Edn., Pustaka National Pte Ltd., Changi Road, Singapore, ISBN-13: 9789971775957.

Rashid, R.A. and N.I. Yaakub, 2015. Masalah kegagalan dan kelewatan pengagihan harta pusaka di Malaysia. J. Intelek.

Saaltink, M., 1997. The Z/EVES system. Proceedings of the 10th International Conference of $Z$ Users on The $\mathrm{Z}$ Formal Specification Notation, Apr. 03-04, Springer, Berlin, pp: 72-85.

DOI: $10.1007 / \mathrm{BFb} 0027284$
Said, I.M., 2006. Perbahasan Dewan Rakyat Kesebelas, penggal ketiga, Mesyuarat Pertama.

Saizan, Z. and D. Singh, 2018. Cyber security awareness among social media users: Case study in GermanMalaysian Institute (GMI). Asia-Pacific J. Inform. Technol. Multimedia, 7: 111-127.

SDLM, 2017. Selangor Department of Land and Mines. Permohonan Hakmilik Hilang/Hancur/Rosak, Pejabat Tanah dan Galian, Selangor.

SED Act, 1955. Small Estates (Distribution) Act.

Shukur, Z., E. Burke and E. Foxley, 1999. Automatically grading customer confidence in a formal specification. J. Comput. Higher Educ., 11: 86-119.

Shukur, Z. A. Mohd Zin and B. Idrus, 2005. Pemodelan Perisian Menggunakan Z. 1st Edn., Penerbit Universiti Kebangsaan Malaysia, ISBN-10: 9679427455.

Wan Hassan, W.Z., J. Alias, N. Muslim, N. Yunos and A. Umar, 2014. The practice of interfaith inheritance distribution in Malaysia: An analysis of its Fatwa. Middle-East J. Scientific Res., 22: 464-469. DOI: 10.5829/idosi.mejsr.2014.22.03.21884

Waugh, R., 2012. No wonder hackers have it easy: Most of us now have 26 different online accounts-but only five passwords. Mail Online. 